\title{
ULTRASTRUCTURE OF SYNOVIAL MEMBRANE IN RHEUMATOID ARTHRITIS
}

\author{
BY \\ F. N. GHADIALLY AND S. ROY \\ Department of Pathology, University of Sheffield
}

Many reports describing the electron microscopic appearance of normal synovial membrane have appeared in the literature in recent years. Two types of lining cells (Type A and B) are seen in synovial membrane of man (Barland, Novikoff, and Hamerman, 1962; Roy, Ghadially, and Crane, 1966), rabbit (Ghadially and Roy, 1966), guinea-pig (Wyllie, More, and Haust, 1964) and rat (Roy and Ghadially, 1967). Reports on the ultrastructure of rheumatoid synovium are comparatively fewer.

Barland, Novikoff, and Hamerman (1964), in a study restricted to the lining cells, observed many changes in Type A cells but the Type B cells appeared normal. However Wyllie, Haust, and More (1966) described, in addition to the changes in the Type A cell, an increase in the number of Type B cells in rheumatoid synovium.

Structural alterations have been observed in the vascular endothelium of the rheumatoid synovium by Hirohata and Kobayashi (1964) which however could not be confirmed in the study of Norton and Ziff (1966). Highton, Caughey, and Rayns (1966) described the presence of rod-shaped inclusions in vascular endothelial cells in rheumatoid synovium, these authors failed to see such bodies in the synovial vessels in normal individuals or in cases of torn meniscus.

In the studies mentioned above no uniform picture of the fine structure of rheumatoid synovial membrane has emerged. It is the purpose of this paper to describe the synovial cell, the matrix, and the vascular endothelium in rheumatoid arthritis in greater detail.

\section{Material and Methods}

Synovial membrane was collected during synovectomy from six cases of rheumatoid arthritis acceptable as "definite" cases according to the criteria of the American Rheumatism Association (Ropes, Bennett, Cobb, Jacox, and Jessar, 1959). Two of the specimens were collected from the wrist joint and the remaining four came from the knee. All the patients had been suffering from chronic rheumatoid arthritis for from 3 to 20 years and had received some form of anti-arthritic treatment during the course of their illness. None had received any intraarticular drug therapy.

Each sample of synovium was divided into two parts for light microscopy and electron microscopy. For electron microscopy the tissue was fixed in 1 per cent. buffered osmium and processed according to the method described before (Ghadially and Roy, 1966). Thin sections were mounted on uncoated copper grids, stained with lead citrate (Reynolds, 1963), and examined with an A.E.I. EM6, using an accelerating voltage of 50 or $75 \mathrm{kV}$.

For light microscopy the tissue was fixed in 10 per cent. neutral formalin and processed to paraffin. $5 \mu$ sections were cut and stained with haematoxylin and eosin and with methyl green-pyronin stain for ribonucleic acid.

\section{Light Microscopy}

\section{Results}

All six cases showed the typical histological features of rheumatoid arthritis. There was villous proliferation of synovium with marked infiltration of the sub-synovial tissue with lymphocytes and plasma cells (Fig. 1). Active granulation tissue with many fibroblasts and capillaries was seen in the subsynovial tissues in all six cases. Clumps of dense eosinophilic fibrinoid material was often seen in the synovial layer.

In four cases moderate to markedly increased pyroninophilia of the lining cells for RNA was noted with methyl green-pyronin stain (Fig. 2.) This reaction could be abolished by prior treatment of the section with RNA-ase (Fig. 3).

Fig. 1.-Low-power view of rheumatoid synovium, showing a papillary structure. The inflammatory reaction in the subsynovial tissue is clearly demonstrated. Haemotoxylin and eosin. $\times 50$.

Fig. 2.- Synovial membrane from a case of rheumatoid arthritis. Almost all the synovial cells show an intensely positive staining reaction for RNA. Methyl green-pyronin. $\times 500$.

Fig. 3.- Serial section from same block as Fig. 2, stained with methy green-pyronin after digestion with ribonuclease. The RNA reaction is abolished. $\times 500$. 


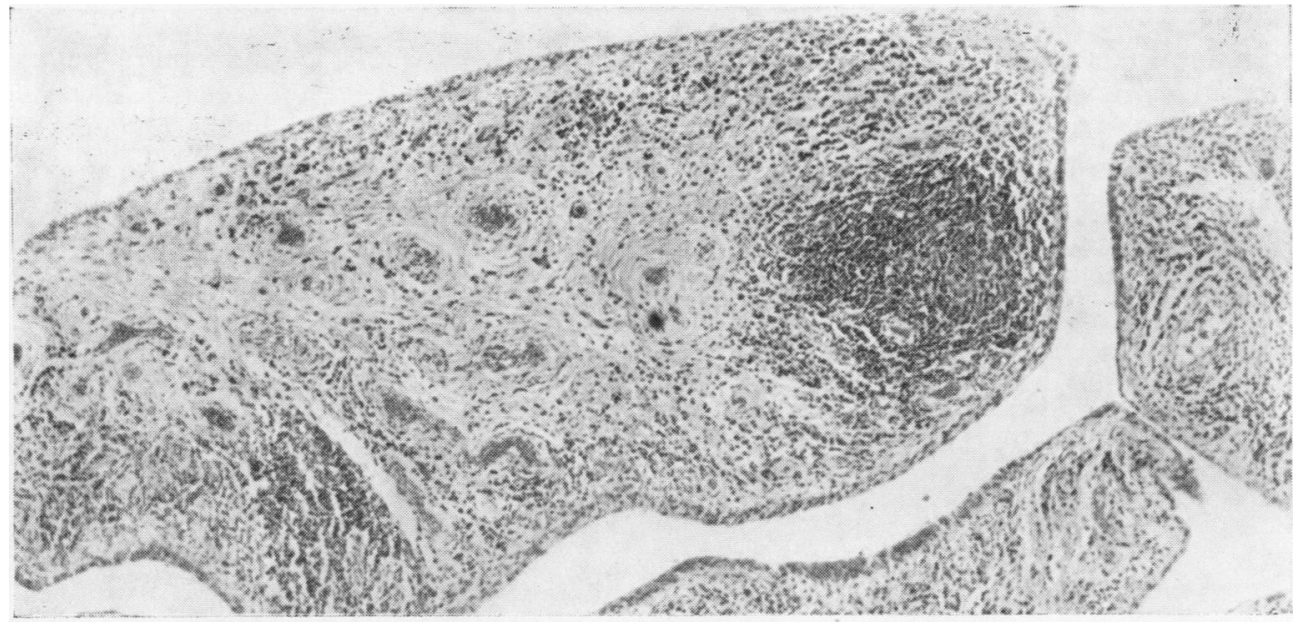

(1)

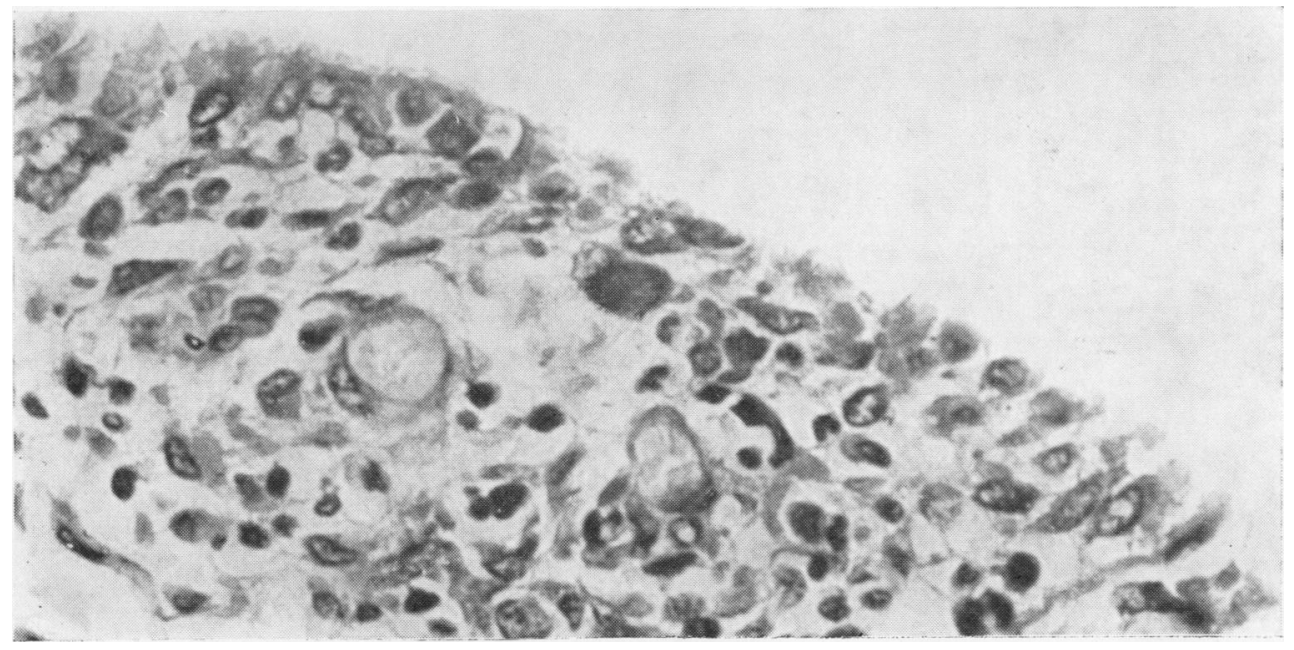

(2)

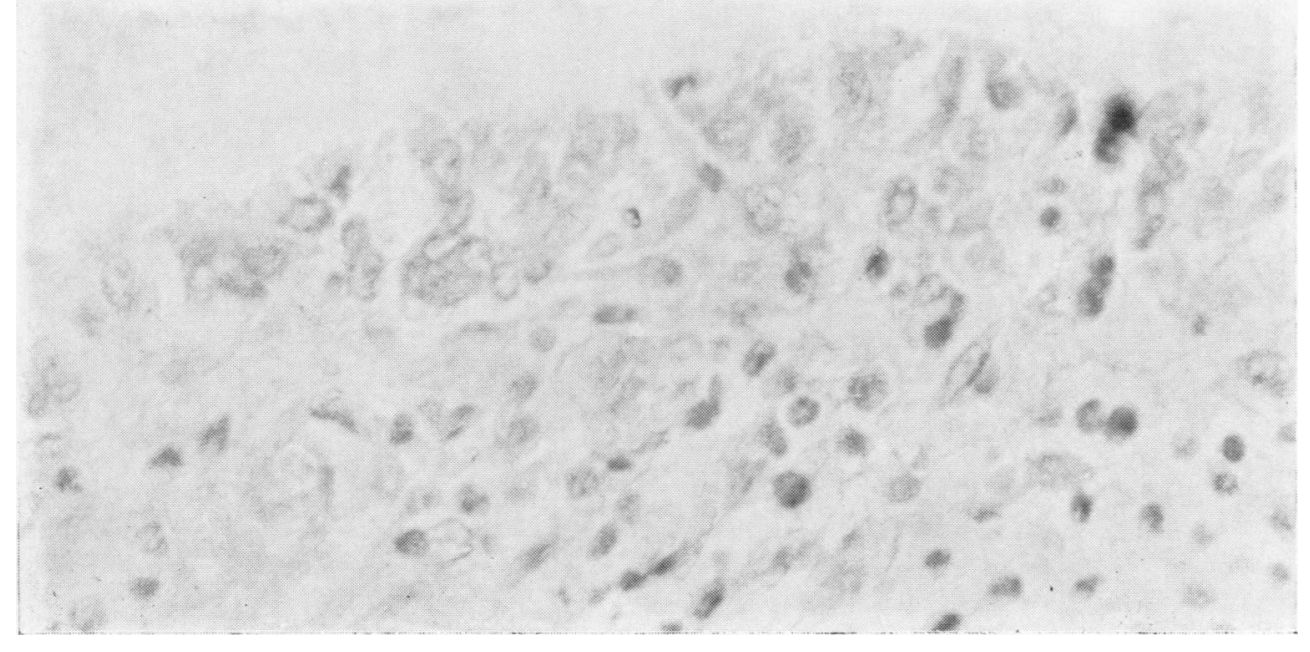

(3) 


\section{Electron Microscopy}

On scanning the sections at low power it was evident that the synovium in rheumatoid arthritis is more cellular than normal. The cells appeared to be closely packed with scanty patches of matrix

between them (Fig. 4). Structural alterations were present in both Type A and B cells. There appeared to be a marked increase in the number of $B$ and intermediate type cells.

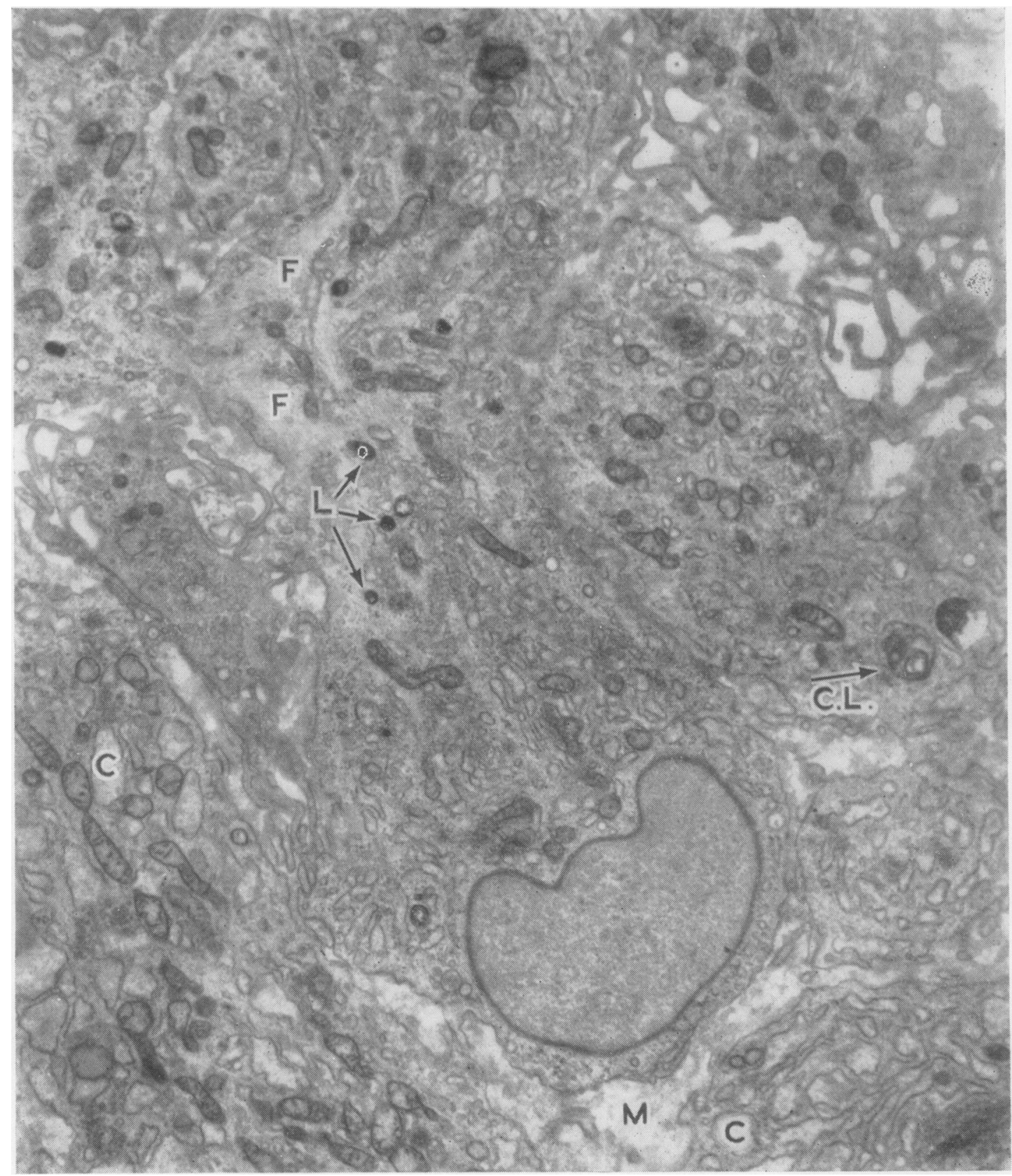

Fig. 4.-Low-power view of rheumatoid synovium, showing increased cellularity and small amount of matrix (M). Most of the cells are Type $B$ and show prominent RER and cisternal dilatation (C). Numerous lysosomes (L), a cytolysome (CL), and areas containing fine filamentous fibres $(F)$ can just be discerned. $\times 3,500$ 


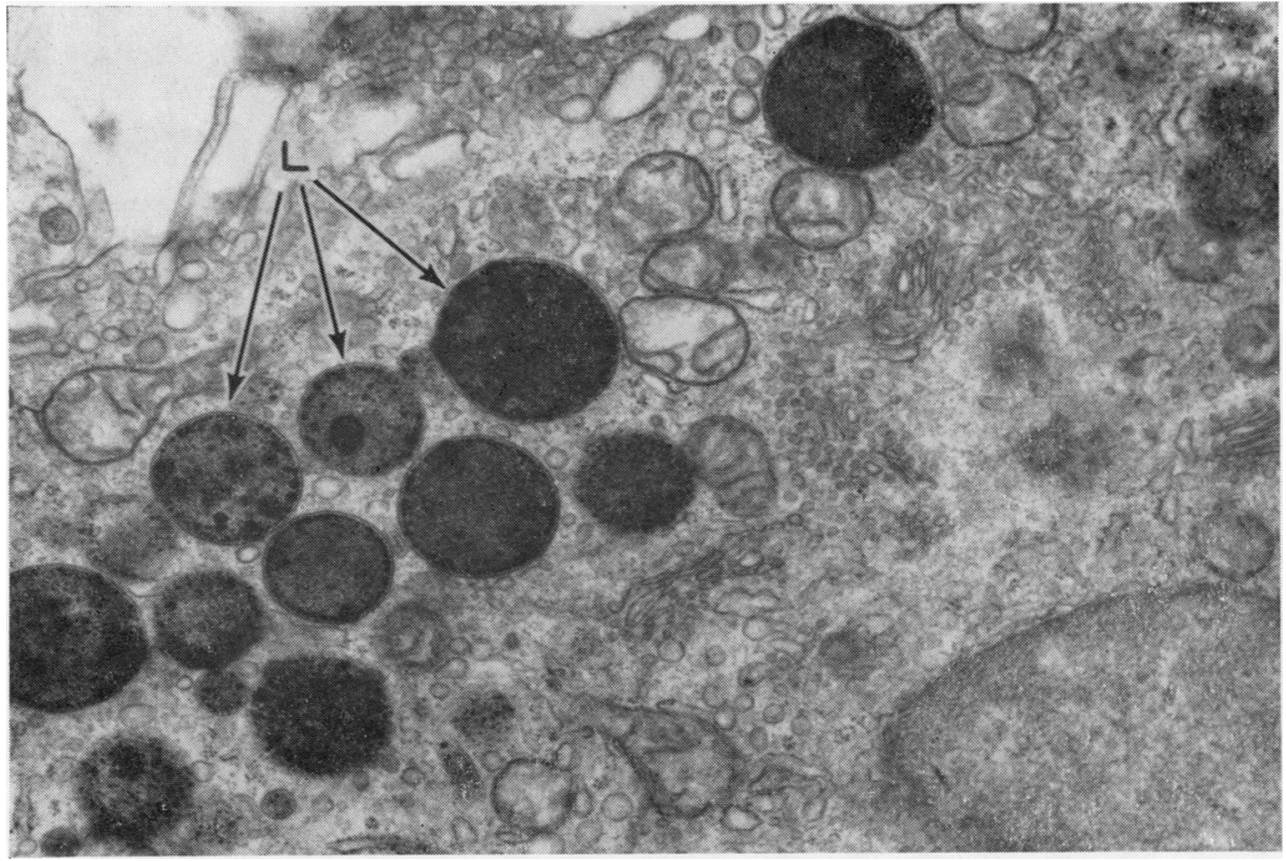

Fig. 5.-Type A cell with characteristic Golgi c o m I e xes, showing a collection of lysosomes (L). 23,000 .

Sub-synovial tissue showed large numbers of plasma cells, lymphocytes, histiocytes, fibroblasts, and capillaries. Fibroblasts and inflammatory cells showed no morphological abnormality. Alterations in vascular endothelia are described later.

Lysosomes.-One of the most striking changes was a marked increase in the number of dense bodies commonly regarded as lysosomes. They were more frequently encountered in Type A cells (Fig. 5). These single membranebound dense bodies show a varied morphology. Sometimes they contain homogeneous, electron dense material or medium density material (Fig. 6). Quite often, however, these organelles contain electron opaque masses and granules set in a medium density matrix (Fig. 6).

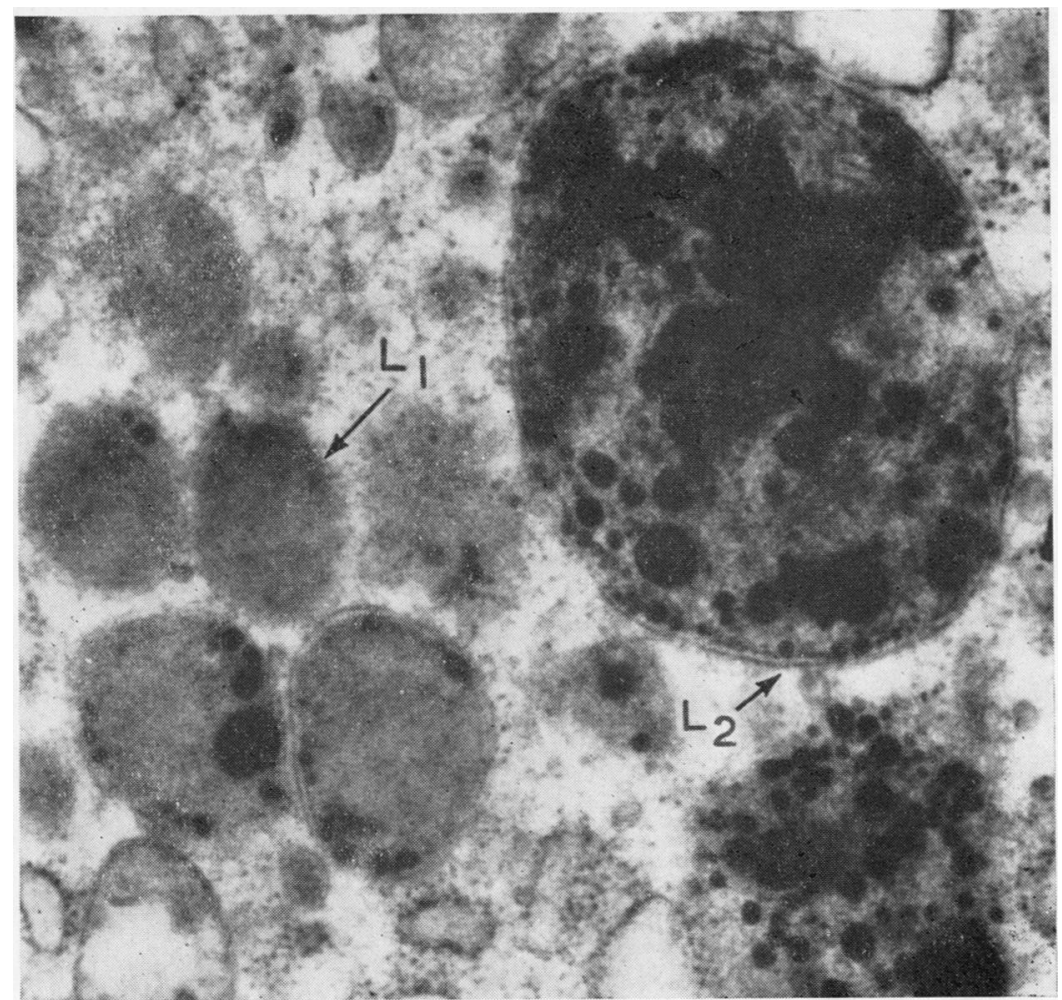

Fig. 6.-Type A cell with some lysosomes containing medium density homogeneous material $\left(L_{1}\right)$, and others with electron dense bodies set in a medium density matrix $\left(L_{2}\right) . \times 45,000$. 
Cytolysomes.-These single membrane-bound inclusions containing membranous and other dense structures were less frequently encountered (Fig. 7).

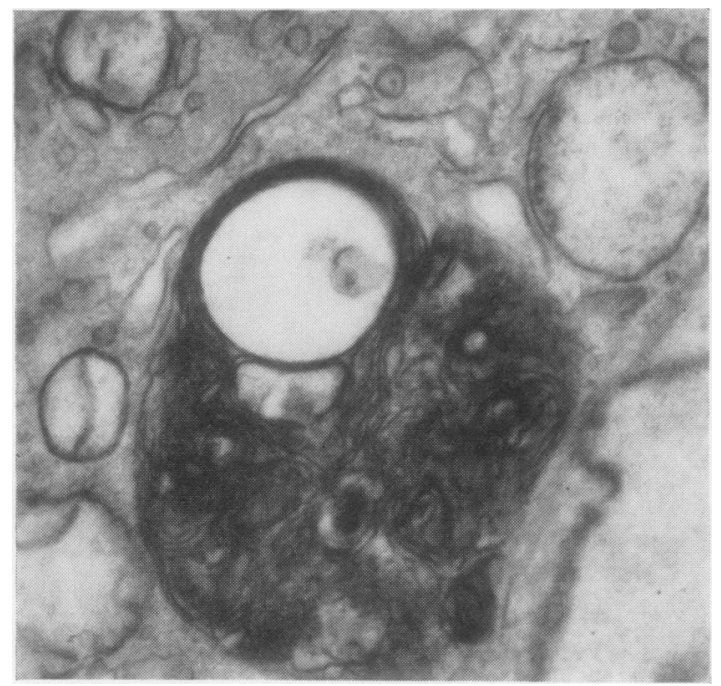

Fig. 7.-Cytolysomes containing membranous structures. $\times 30,400$.
Phagosomes.- "Fibrinoid" material lying on the synovial surface was also at times seen to be phagocytosed by synovial cells.

Fig. 8 (opposite) illustrates this phenomenon. Here we see fibrinoid material lying in the joint space at $\mathbf{A}$ and also engulfed by a filopodium at B. Similar material can also be seen in single membrane-bound vesicles at $C$. These appearances suggest that these dense bodies are probably produced as a result of phagocytosis of fibrinoid material and are hence best regarded as fibrinophagosomes. In Fig. 8 at $\mathrm{D}$ we also see what appears to be a cell fragment surrounded by filopodia, and in Fig. 9 we see another more obvious cell fragment embranced by filopodia. This suggests that cell fragments are phagocytosed by synovial cells as in Fig. 10 (overleaf). However, at this stage one cannot confidently distinguish such bodies from a cytolysome, nor can one, on the basis of a single section, exclude the possibility that this is a herniation of a portion from an adjacent cell.

Rough Endoplasmic Reticulumand RNP Particles.The marked increase in the rough endoplasmic reticulum (RER) is plainly reflected by the increase in Type B and intermediate type cells (Fig. 4). Many RNP particles were also seen lying free in the cytoplasm. Dilatation of the cisternae of the RER

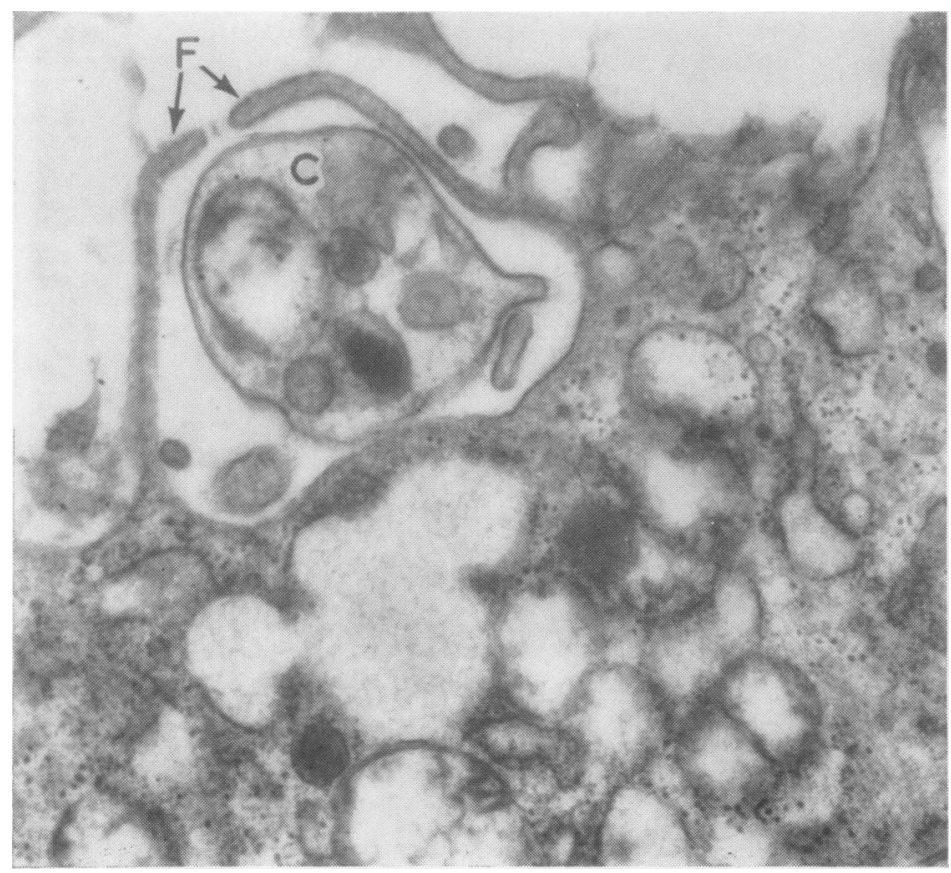

Fig. 9.-Cell fragment (C) embraced by filopodia (F) of synovial cell. $\times 28,500$ 


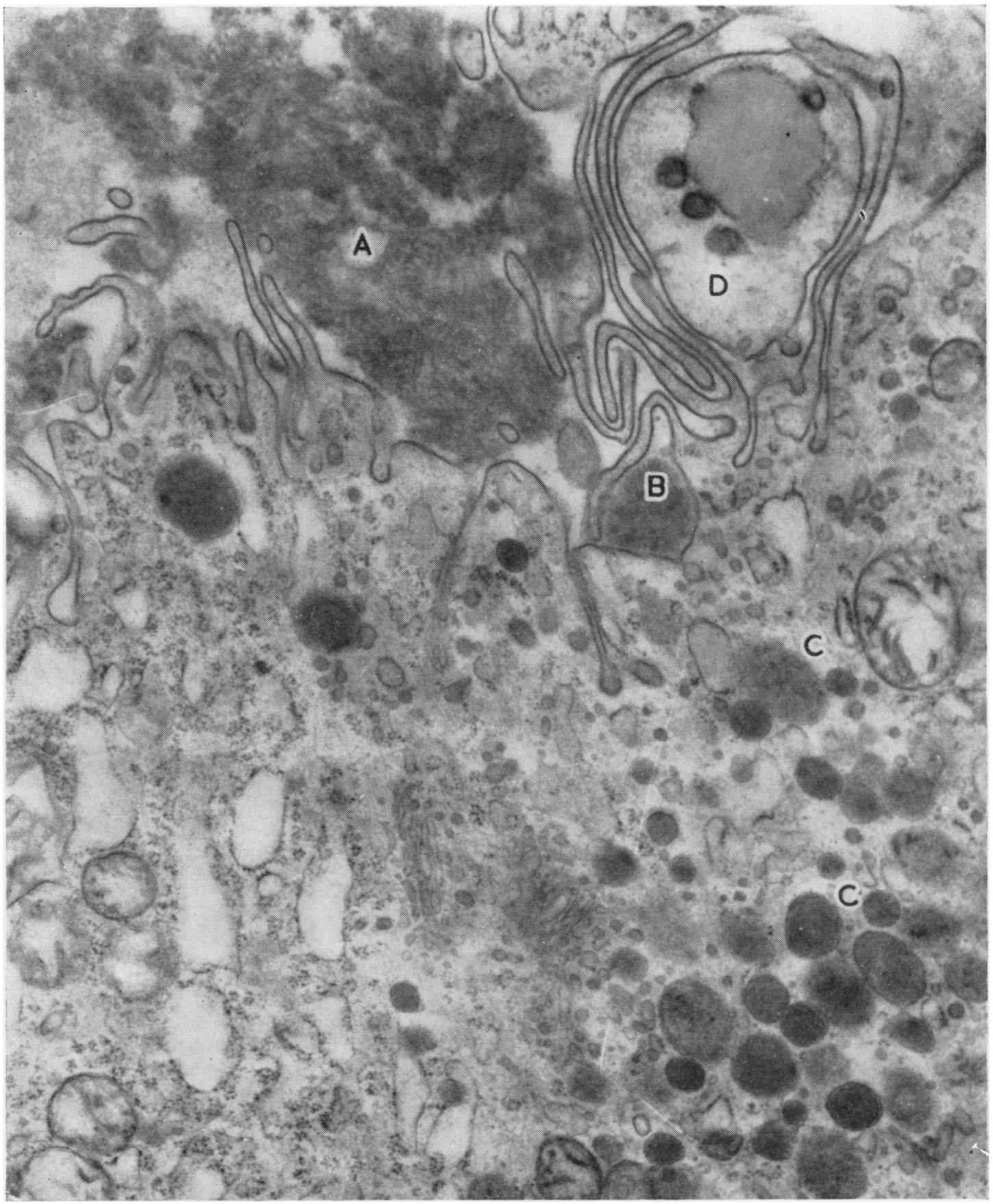

Fig. 8.-Phagocytosis by synovial cell. Fibrinoid material is seen lying in joint space (A) surrounded by a filopodium (B) and witnin the cell (C). $A$ cell fragment containing what appears to be a lipid droplet and some lysosomal bodies is seen at $\mathrm{D}$. $\times 30,000$. 


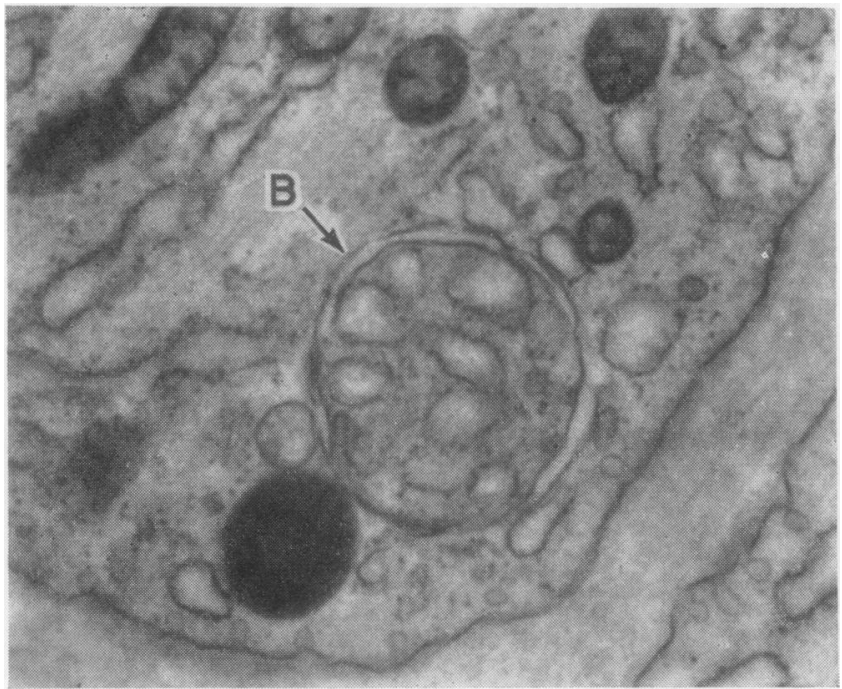
Fig. 10.-Double membrane-bound body (B) in a synovial
cell. $\times \mathbf{3 0 , 0 0 0 .}$

Fig. 11.-Synovial cell with dilated cisternae containing spherical masses (M) of electron dense material.

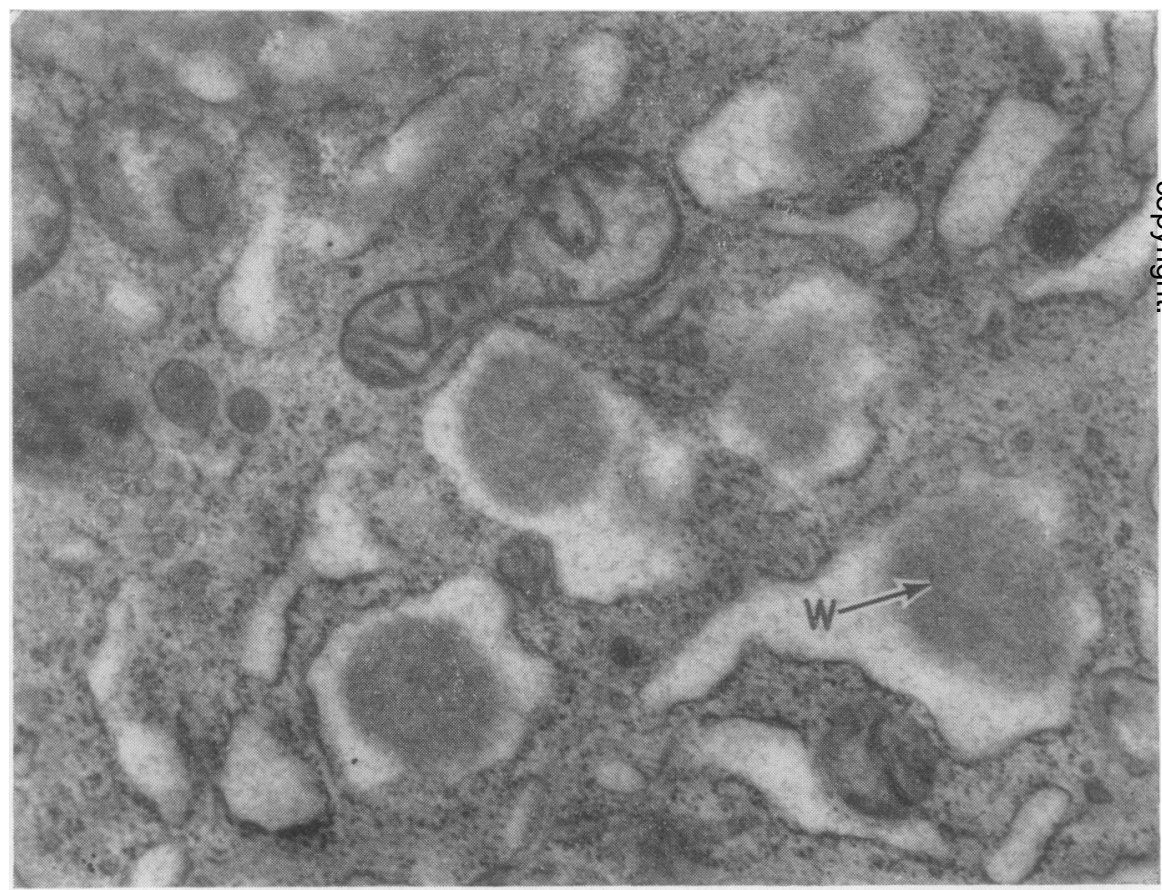

was an extremely common feature, and at times these contained collections of granular and fibrillar material (Fig. 11).

Mitochondria.-In many cells the mitochondrial size and morphology was similar to that seen in the normal synovium (Fig. 12, opposite), but in some instances gross deviations from the normal were encountered. Perhaps the most striking was the occurrence of giant mitochondria.
In Fig. 13 (opposite) we see two large mitochondria the largest measuring $2 \mu$ in length. The mitochondrial matrix shows a flocculent appearance and the cristae are displaced to the periphery of the organelle.

Fig. 14 (overleaf) shows another large complex mitochondrion measuring $2 \cdot 8 \mu$ in length.

A common abnormality was the occurrence of apparently swollen or hydropic mitochondria with peripherally displaced cristae. In extreme samples 


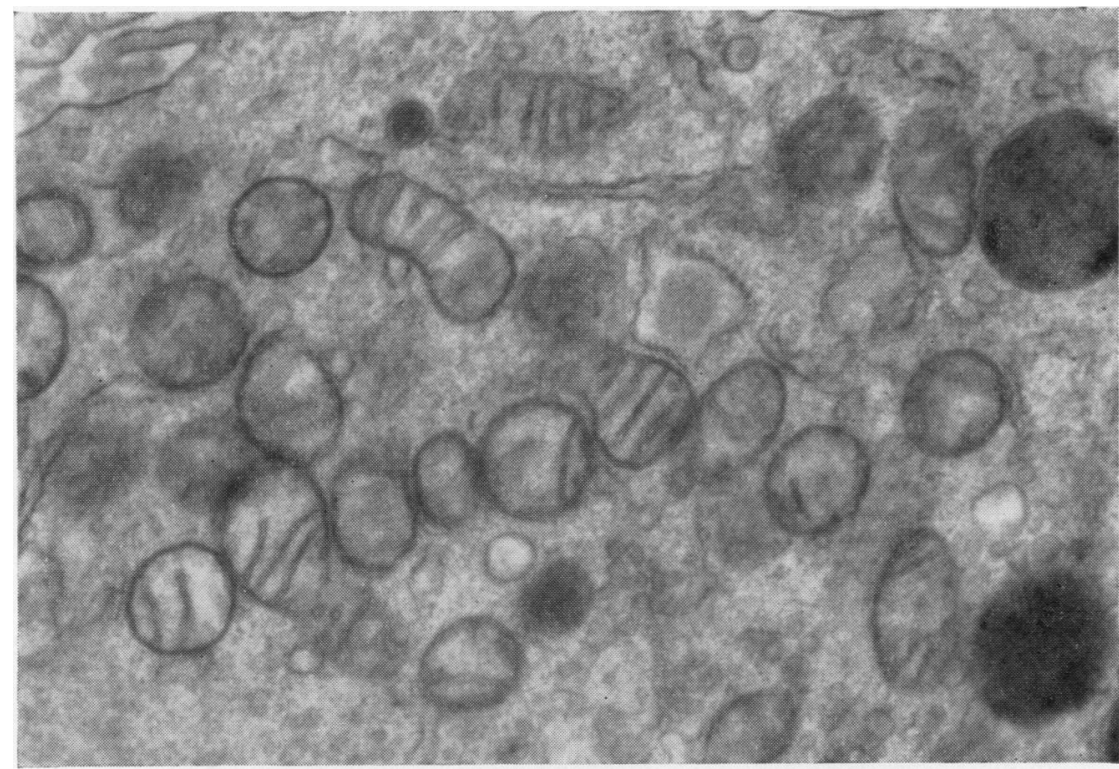

Fig. 12.-Collection of normal-looking mitochondria in a synovial cell. $\times 30.000$,

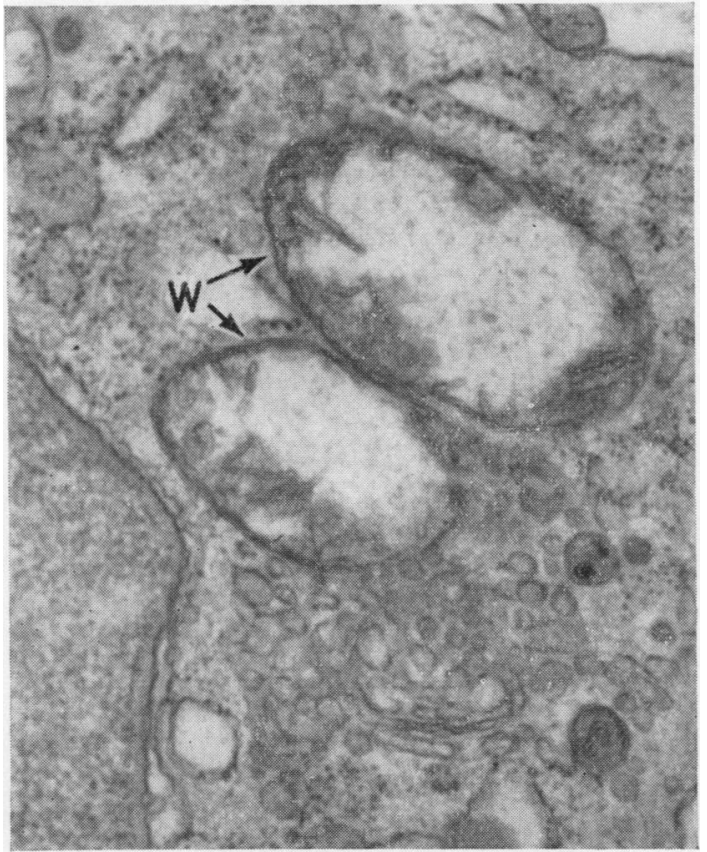

Fig. 13. - Two giant mitochondria (M) with displaced cristae and granular matrix found in a Type A synovia! cell. $\times 32,000$.

(Fig. 15, overleaf), the mitochondrion is converted into a double-walled sac with few or no obvious cristae and an electron lucent matrix. Such hydropic mitochondria are often seen in cells with wellpreserved RER and other organelles, and as such are unlikely to be due to processing artefacts. Mitochondria showing malorientated cristae forming arches or circles are sometimes noted.

Golgi Complex.-No gross abnormalities were detected in this structure, but it is our impression that it is less frequently seen in most of the Type A cells than in the normal synovium.

Fine Filamentous Fibres-A few fine filamentous fibres are frequently encountered in occasional cells of the normal synovium. In all the examples of rheumatoid synovium studied, there was a marked increase in the number of cells showing such filaments. Furthermore, some cells showed massive amounts of fine fibres far in excess of any that we have observed in normal synovium (Fig. 16, overleaf).

In extreme examples almost all the organelles in the cell disappear and the available space is filled with these fine filamentous fibres.

Amorphous Electron Dense Inclusions-In one of the cases studied we found amorphous inclusions in synovial cells hitherto unrecorded in the literature and whose significance is obscure. They appear to be irregular, elongated objects without any limiting membrane. 


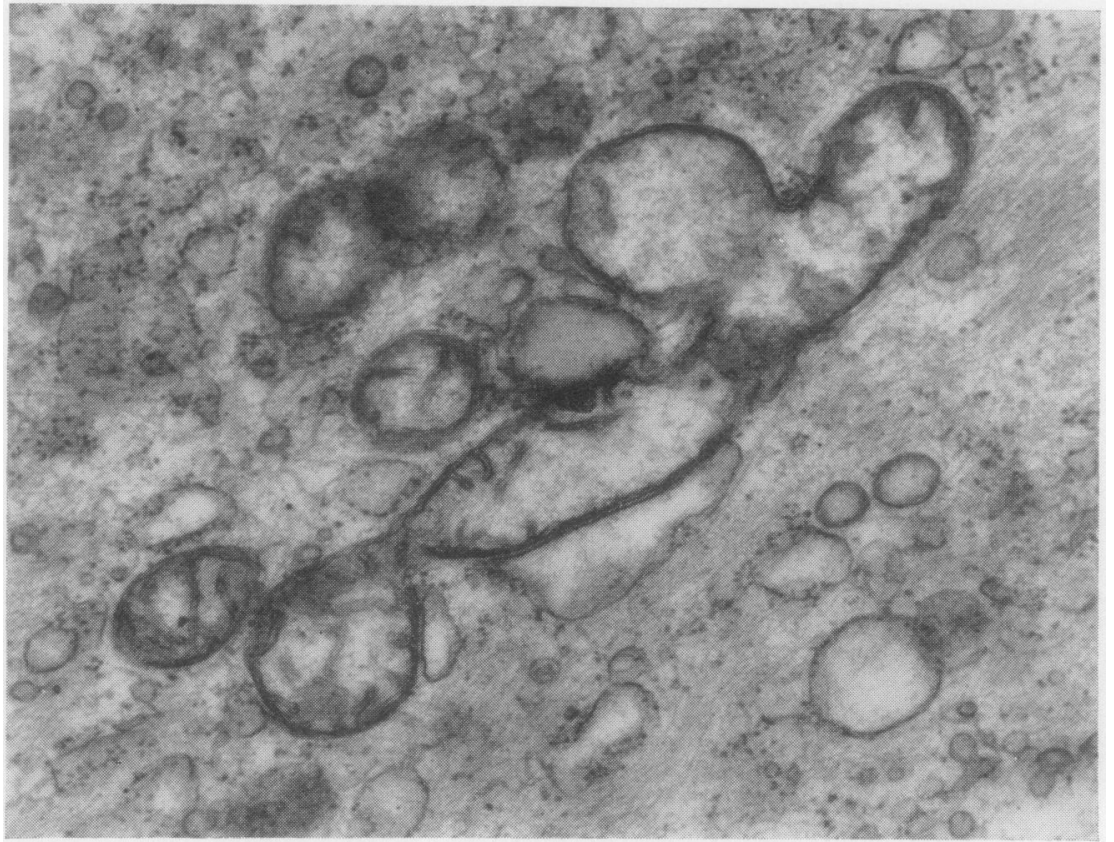

Fig. 14.-Large complex mitochondrion. $\times 37,000$

Fig. 15.-Hydropic mitochondiar with electron lucent matrix (M). An amorphous electron dense inclusion (D) is seen surrounded by fine dense inclusion (D) is seen surrounded by fine
filamentous fibres (F) in Type B synovial cell (F) in Type
$\times \quad 37, \mathrm{C} 00$.

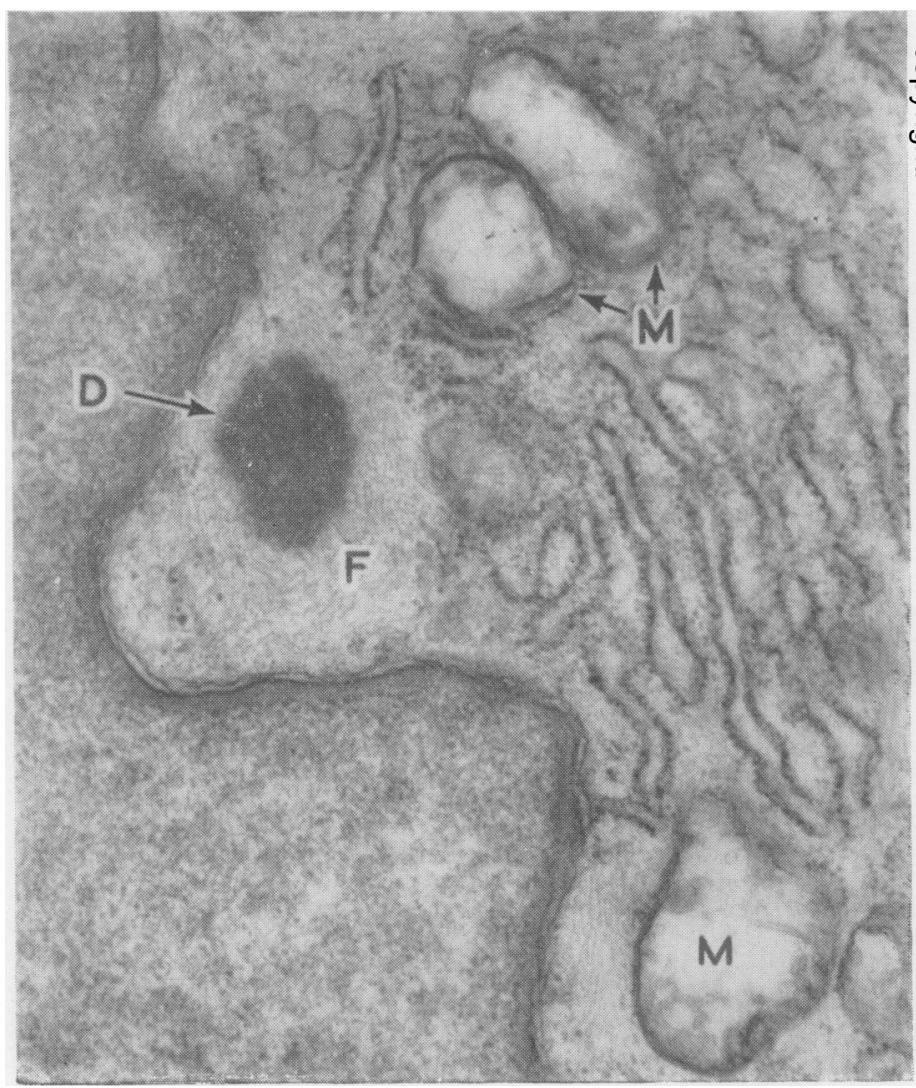




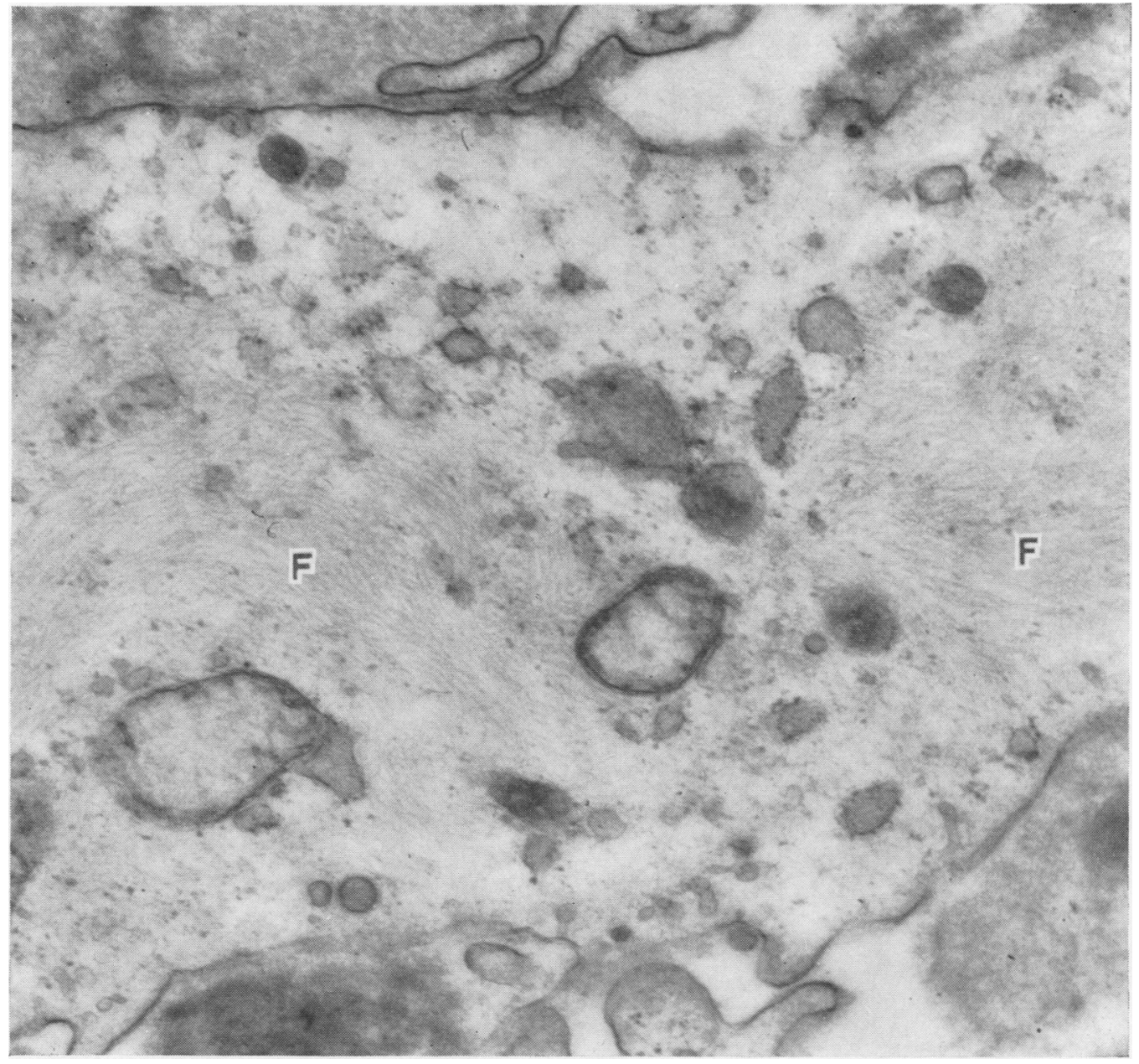

Fig. 16.-Synovial cell showing replacement of normal cellular architecture by fine filamentous fibres (F). $\times 37,000$.

Figs 15 (opposite) and 17 (overleaf) show a transverse and longitudinal section through these inclusions. They invariably occur in a zone where fine filamentous fibres abound.

Lipid-Lipid droplets of characteristic morphology (Fig. 18, overleaf) were frequently seen in the synovial cells of all six cases. These medium density droplets are surrounded by and peppered with small electron dense granules. Occasionally more electron dense lipid droplets were also encountered.

Electron Dense Granules-Electron dense granules (Fig. 19, overleaf) were frequently seen in the synovial cells in three of the six cases studied. It was considered that these could be particles of either haemo- siderin or glycogen. A study of serial sections stained with lead and uranium revealed that these particles stained poorly or not at all with uranium (Fig. 20, overleaf). It would appear therefore that this is a monoparticulate glycogen (Biava, 1963).

Matrix and Joint Cavity-Both periodicallybanded collagen fibres and aperiodic fibres were seen in the matrix of all cases of rheumatoid synovium. We could not detect an overt increase in collagen as reported by Wyllie and others (1966). The only clear-cut pathological change was the deposition of electron dense fibrillar material (Fig. 21 , overleaf) in some foci in the matrix and in patches on the synovial surface. Unlike fibrin, this 


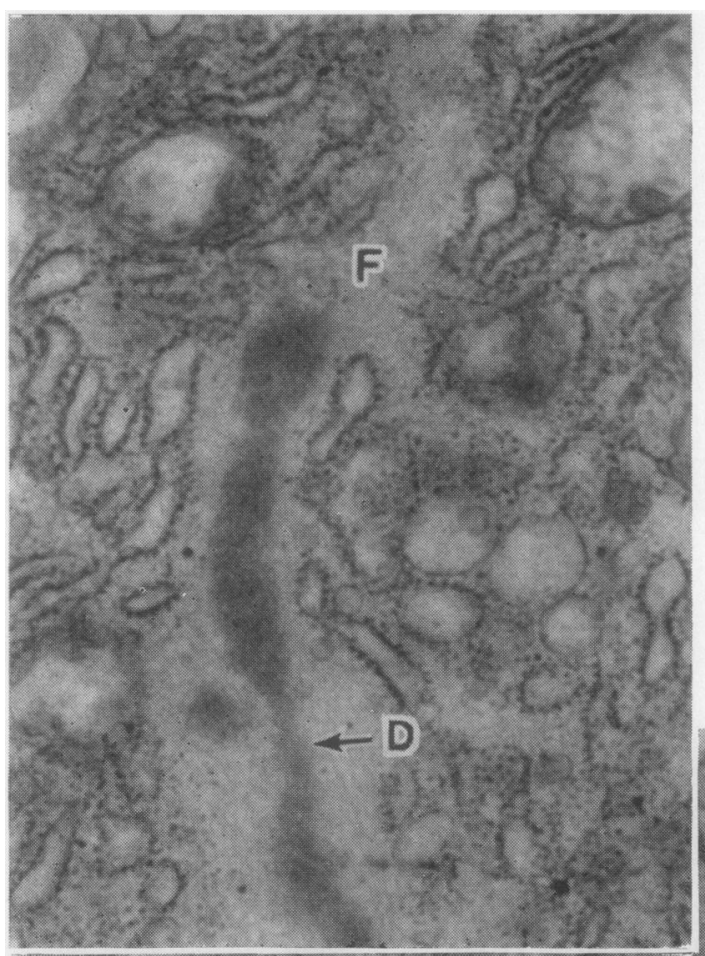

Fig. 17. - Amorphous electron dense inclusion (D) surrounded by fine filamentous fibres $(F) . \quad \times 37,000$

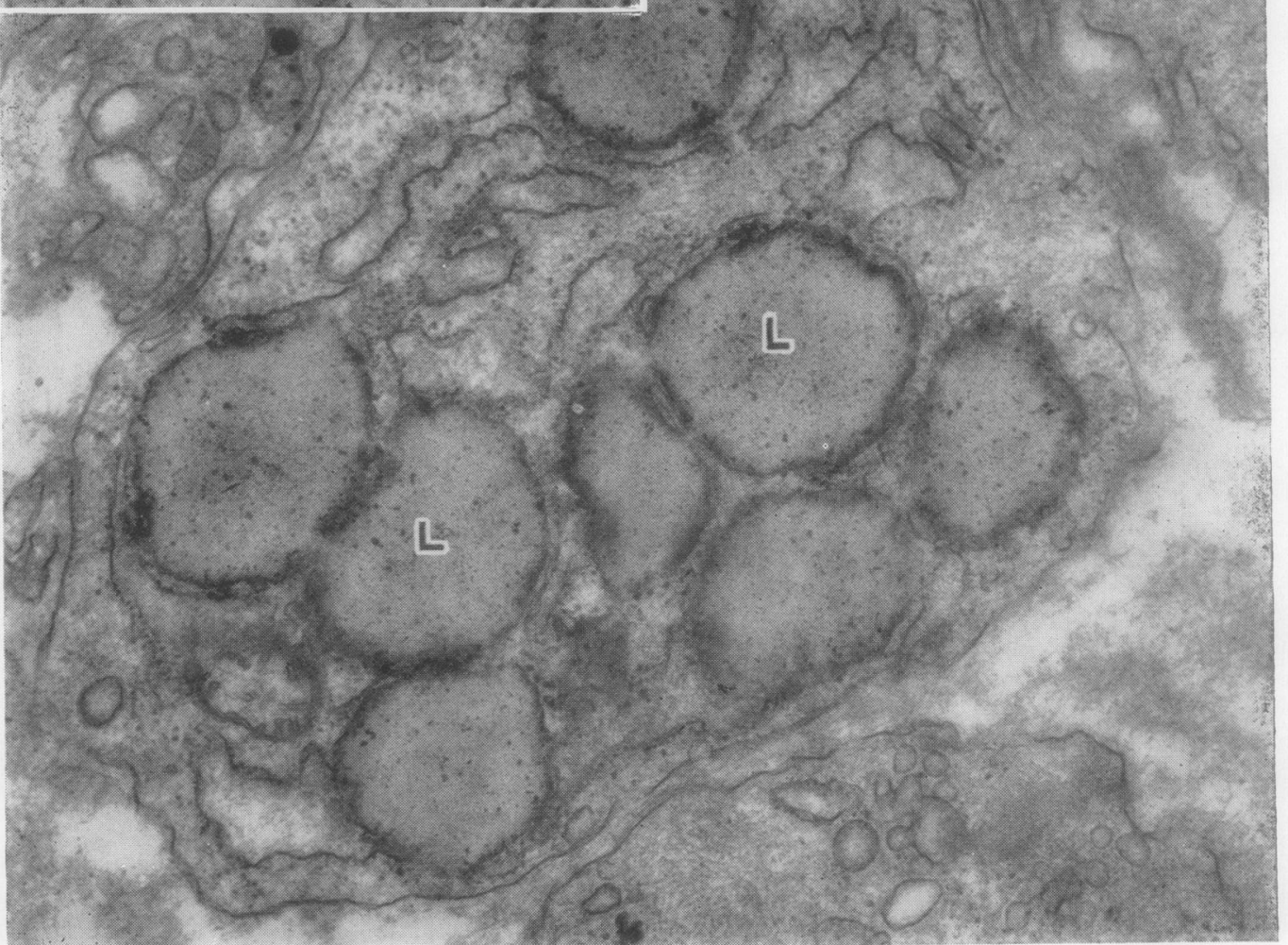




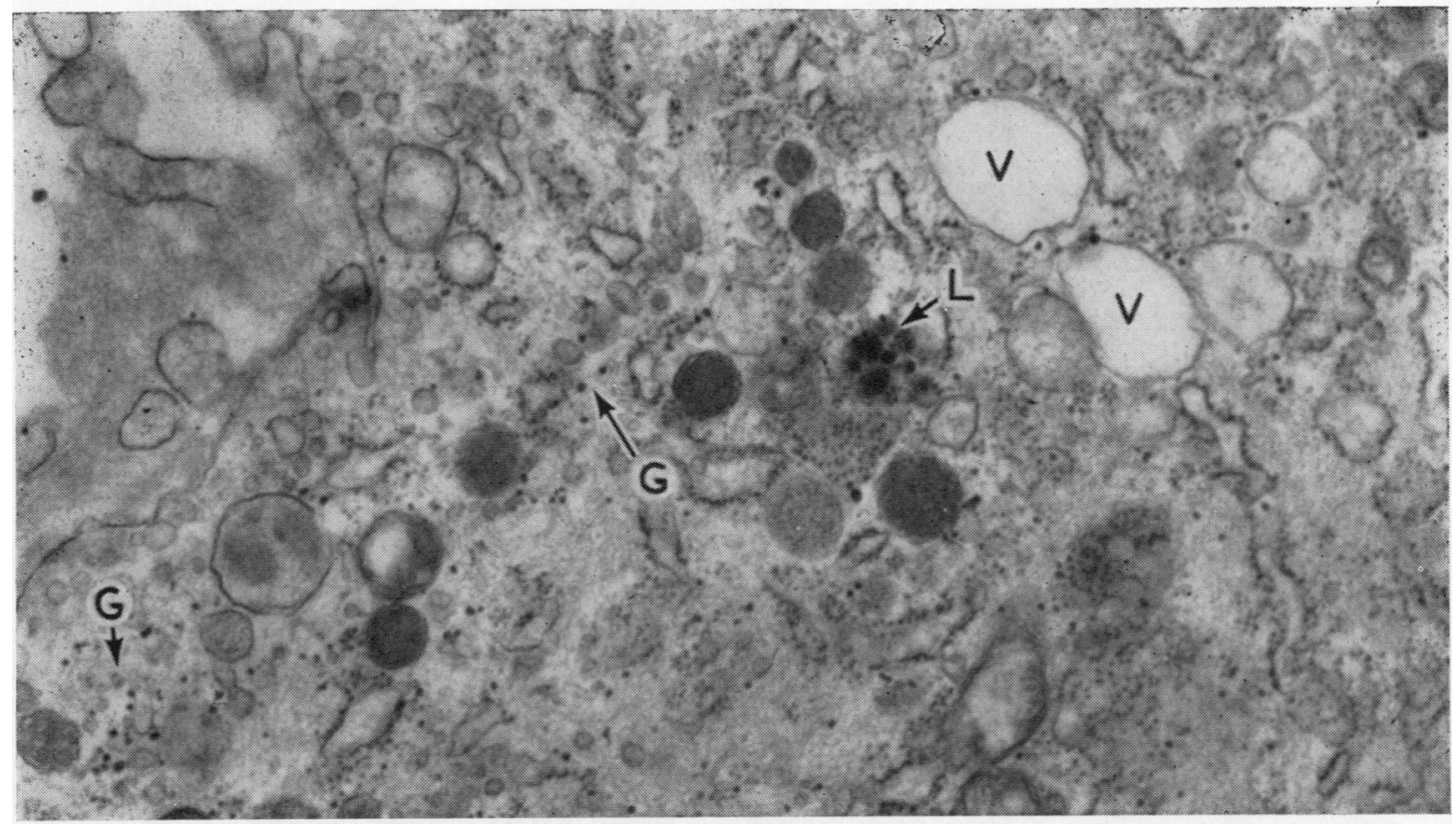

Fig. 19.-Synovial cell stained with lead citrate, showing electron dense granules (G.) Note vesicles (V) and lysosomal body (L). Compare with Fig. 20. $\times 35,000$

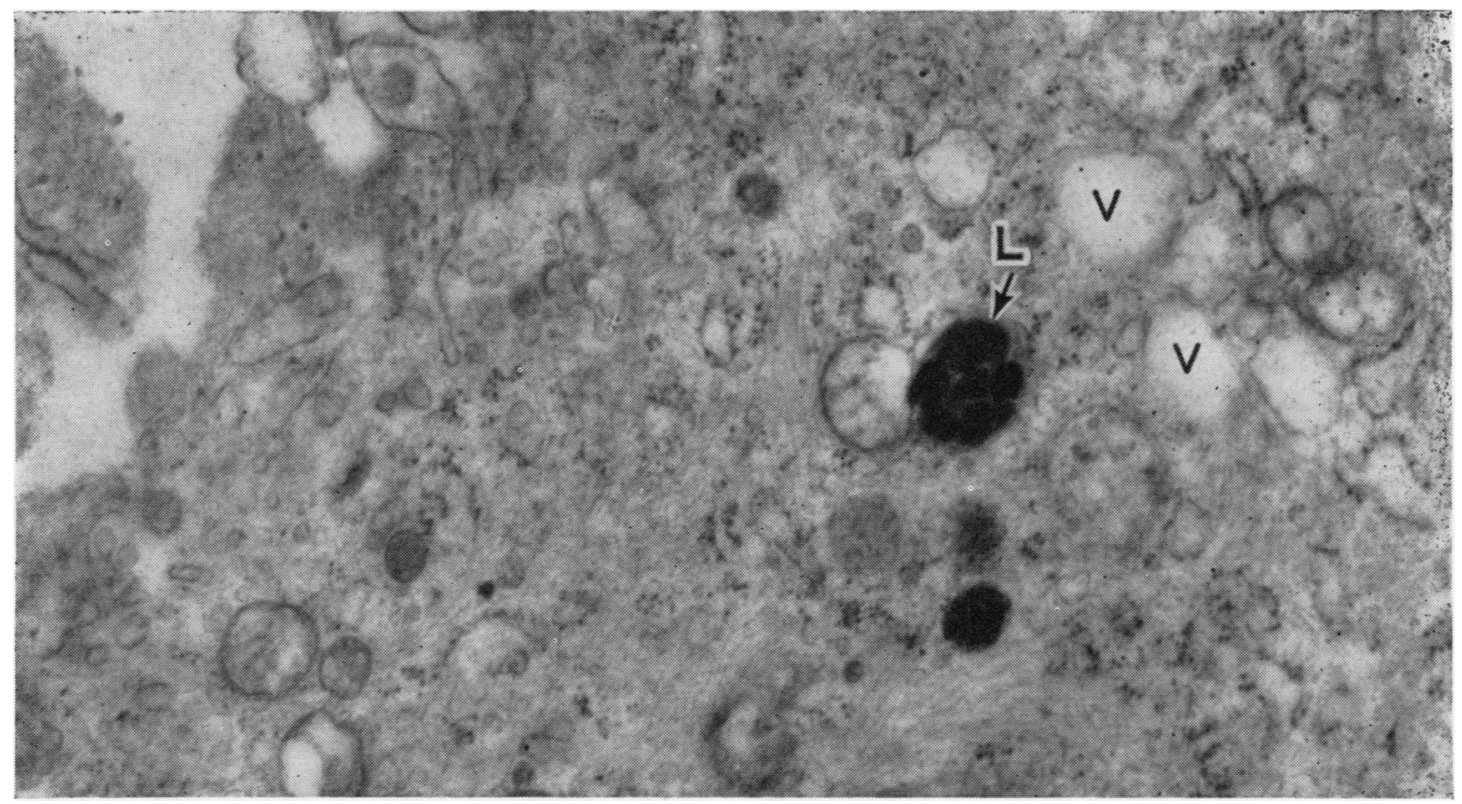

Fig. 20.-Adjacent section from the cell illustrated in Fig. 19, with vesicles (V) and lysosomal body (L) in a similar position. In this instance the section was stained with uranul acetate. No electron dense particles can be clearly discerned, although Palade granules (ribosomes) can be seen. $\mathbf{E}$ $\times 35,000$. 


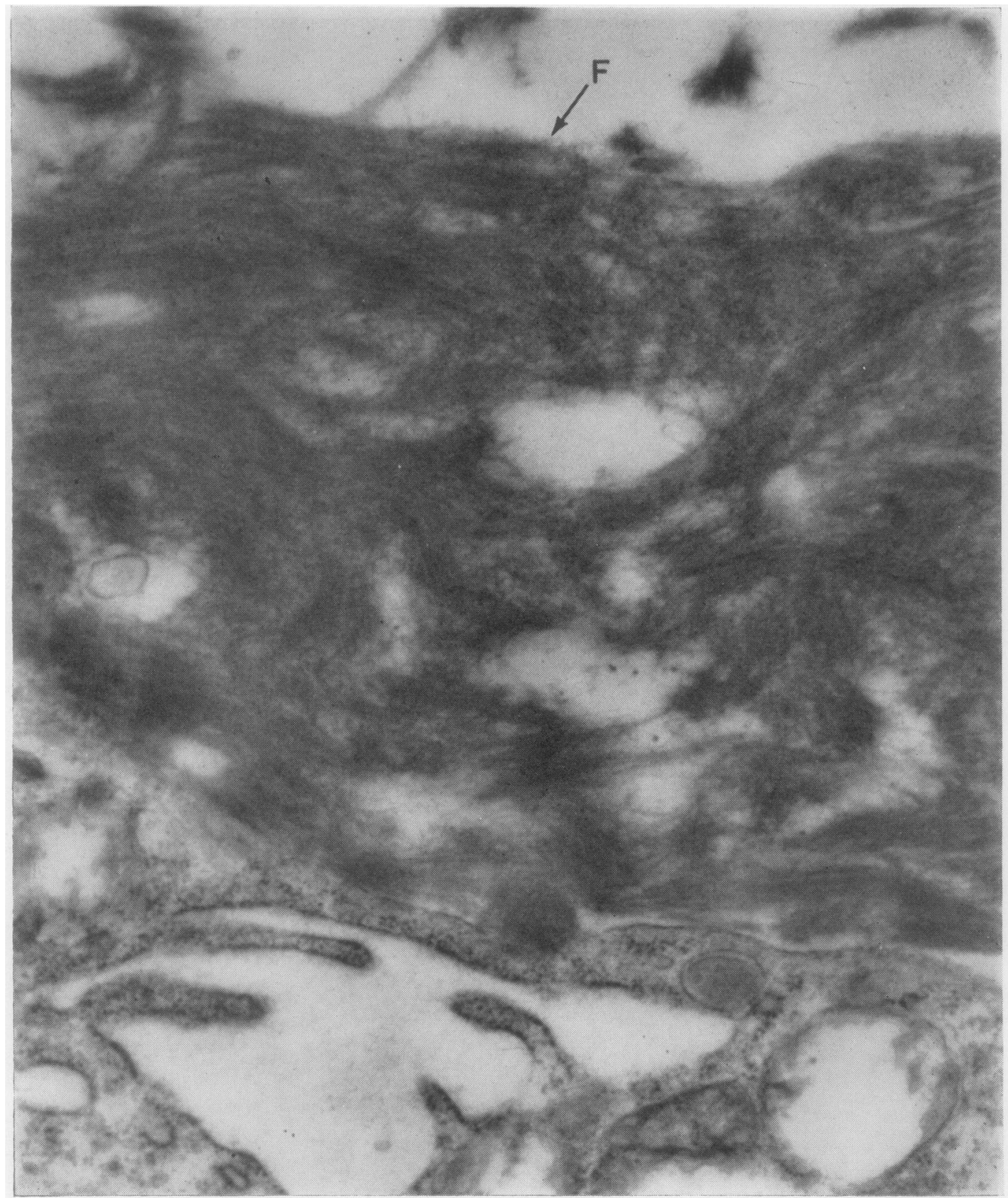

material does not show cross striations and corresponds to the material seen with light microscopy as "fibrinoid". Similar material has also been observ- ed by Norton and Ziff (1966) and was described by these authors as "fibrin-like", but the nature of this material is obscure. 
Synovial Blood Vessels - In all the six cases studied filamentous fibres. This is clearly seen in all the the endothelial cells contained large amounts of fine cells lining the capillary in Fig. 22. Here again, as in

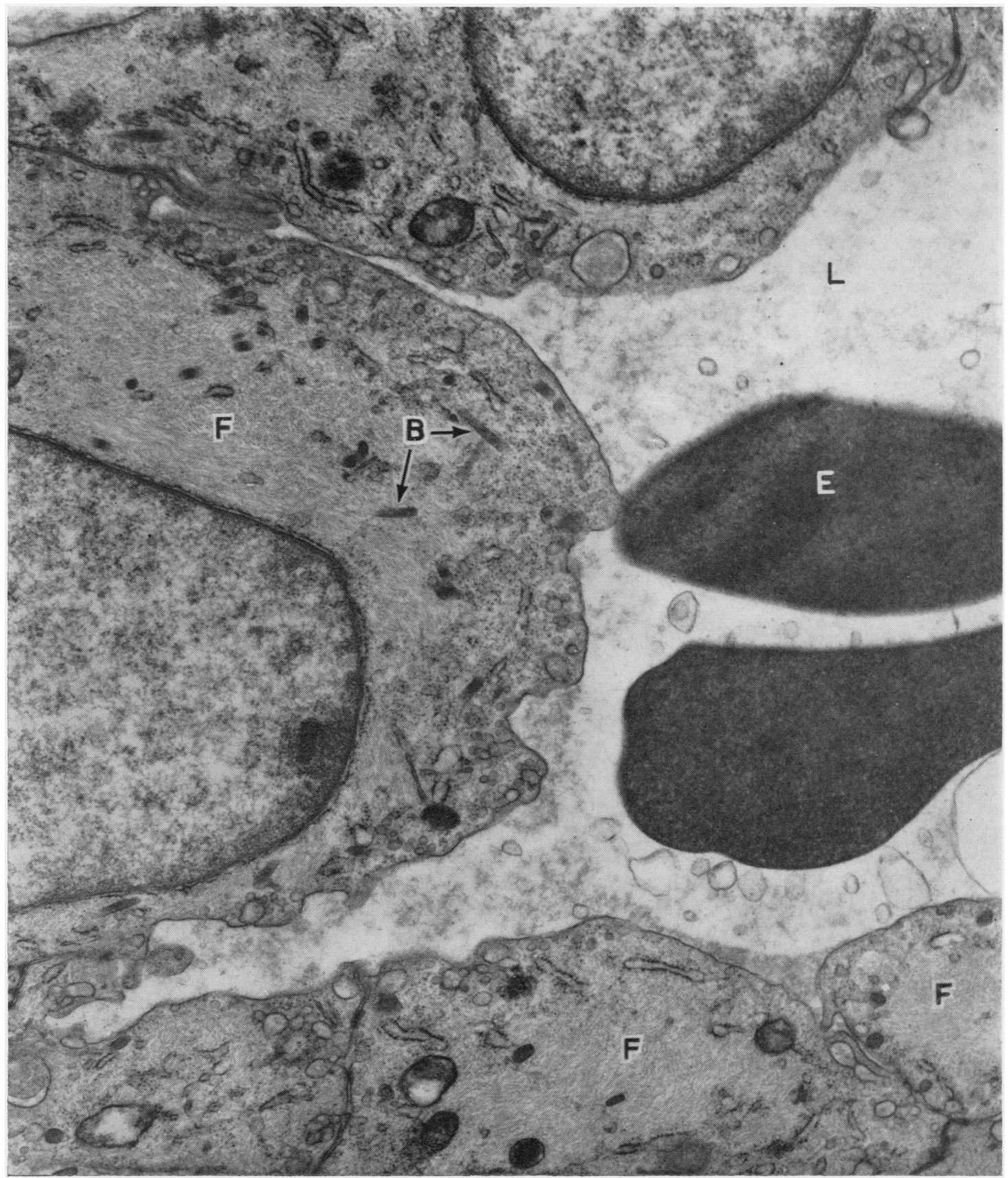

Fig. 22. - Capillary endothelium, showing fine filamentous fibres (F) and rod-shaped bodies (B). Erythrocytes (E) are seen in the lumen (L). $\times 19,000$. 
the synovial cells, the normal intracellular components are either displaced or destroyed in zones where this change occurs. Such a view is supported by Fig. 23, which shows a disintegrating mitochondrion enmeshed in these fibres.

Rod-shaped bodies (Figs 22 and 24) were seen in some of the endothelial cells of five of the six cases studied. These bodies have a diameter of approximately $0 \cdot 1 \mu$ and contain tubular elements about 150 $\AA$ in diameter. These rod-shaped bodies are, in our view, similar to those seen by Highton and others (1966) in the rheumatoid synovium and by Weibel and Palade (1964) in normal endothelia in various organs of man and rat.

Dense bodies, presumably lysosomes, were also occasionally seen in the endothelial cells of all cases.

\section{Discussion \\ Lysosomes and Cytolysomes \\ The presence of large numbers of lysosomes and cytolysomes in rheumatoid synovia has already been described by Barland, Novikoff, and Hamerman}

(1964), Hirohata and Kobayashi (1964), and Wyllie, Haust, and More (1966). Our findings confirm these observations. Such bodies have been shown to contain acid phosphatase (Barland and others, 1964). The presence of cytolysomes in areas undergoing focal cytoplasmic degeneration is seen in many other situations (Novikoff and Essner, 1962; Hruban, Spargo, Swift, Wissler, and Kleinfeld, 1963; Parry and Ghadially, 1965). The agent responsible for causing such damage to the synovial cells in rheumatoid arthritis is not known. As similar bodies do occur in other cells as a response to various forms of injury, it canncit be taken as a specific change occurring in synovial cells in cases of rheumatoid arthritis. In fact, we have observed cytolysomes in the synovial cells in cas ss of traumatic effusion in man (Roy and others, 1966) and also in experimentally-induced haemarthrosis in rabbits (Roy and Ghadially, 1966). It seems to us that such a change is rather non-specific and secondary to a variety of noxious stimuli. Whether this stimulus in cases of rheumatoid arthritis is in

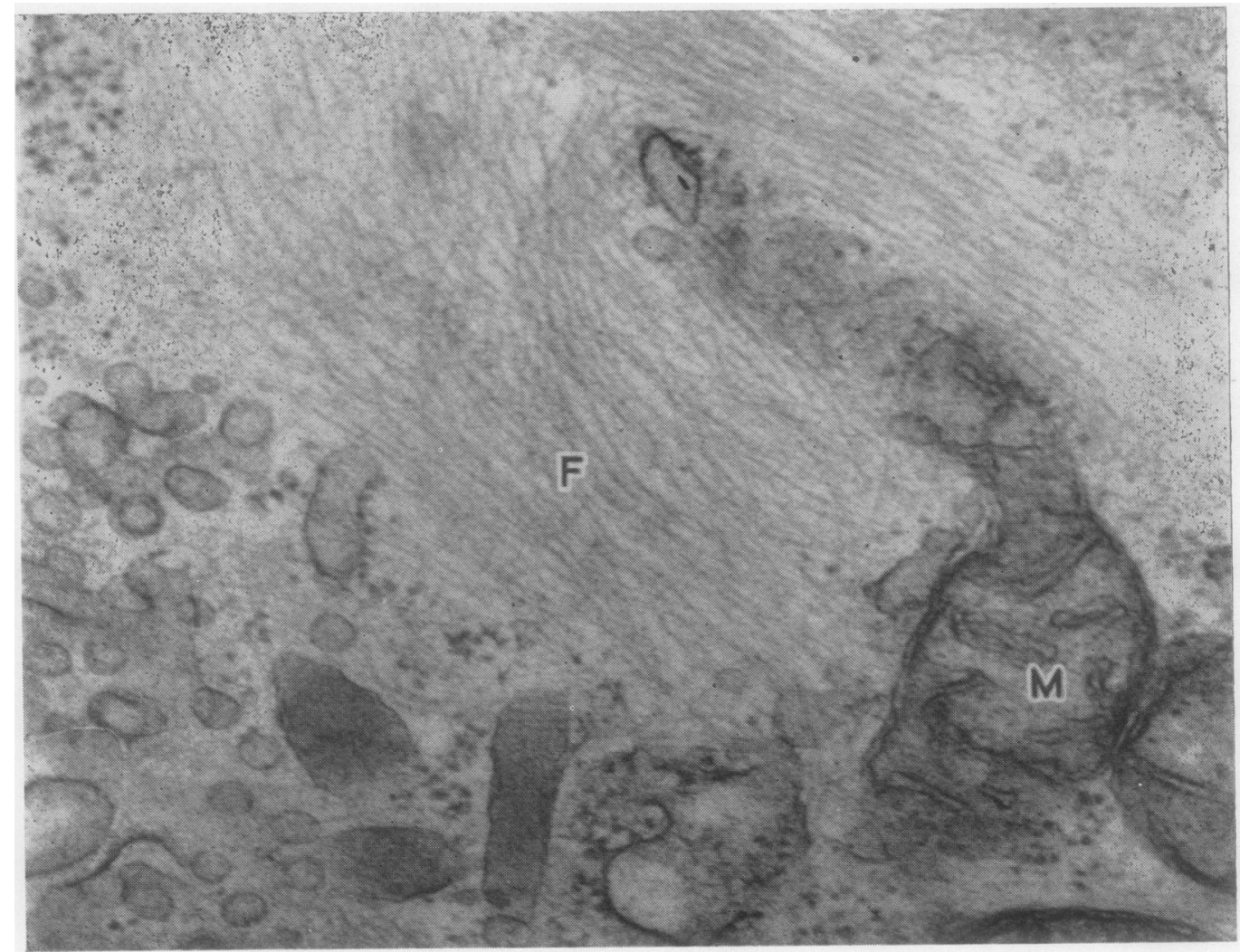

Fig. 23. - Capillary endothelium, showing an apparently disintegrating mitochocondrion $(M)$ in a zone of fine filamentous fibres $(F) . \quad \times 70,000$ 


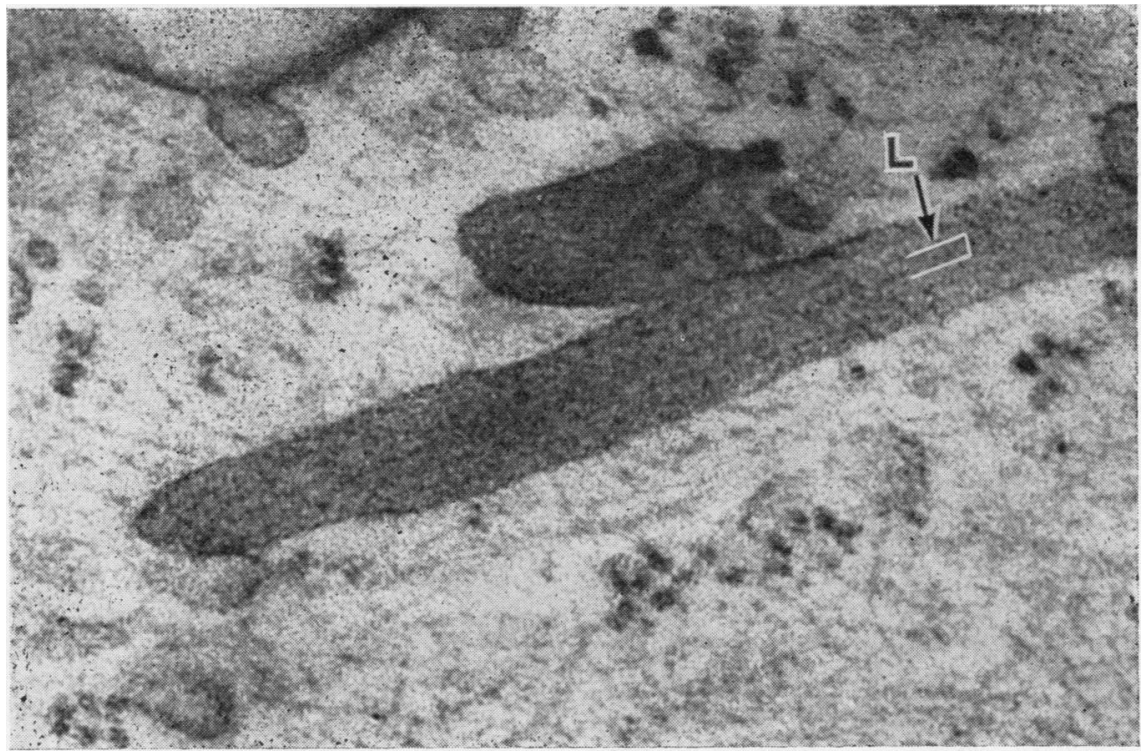

Fig. 24. - Longitudinal sections of a rod-shaped body at higher magnification. It contains indistinct laminar formation (L) representing the wall of longitudinally-arranged tubular structures. $\times 140,000$.

fact a virus, as suggested by Barland and others (1964), remains merely speculative at this stage. We have also observed varying structural changes in the mitochondria of the synovial cell. Such changes are probably caused by the same agent responsible for focal cytoplasmic degeneration of synovial cells. This finding is in conformity with the observation of Barland and others (1964).

\section{Hyperplasia of RER and Protein Synthesis}

Barland and others (1964) and Norton and Ziff (1966) found no alteration in Type B cells in rheumatoid arthritis, but Wyllie and others (1966) described an increase in Type B cells with no significant structural alterations therein. In the present study, too, we found an increase in the Type B cell population. In many of these cells the dilated cisternae contained electron dense granular of fibrillar material. This appearance seems to indicate that the synovial cells are stimulated to form more protein in rheumatoid arthritis. That the normal synovial cells are capable of protein synthesis has been recently demonstrated (Roy and others, 1966). Wyllie and others (1966) also considered this possibility and suggested that the synovial cells form collagen in theumatoid arthritis. In their study, the presence of collagen in the matrix of the synovium was a prominent feature. In the present study, however, we were unable to detect any periodically-banded collagen in the superficial zone of the matrix and it was only rarely present in the middle zone. We have no evidence to support the idea that Type B cells form any collagen in normal or rheumatoid synovium.

It is, however, probable that these cells form some protein which is contributed to the synovial fluid. It has been shown that normal synovial fluid contains about 2 per cent. protein which is firmly bound to hyaluronic acid (Sandson and Hamerman, 1962). Although most of the proteins in synovial fluid, both in normal conditions and in rheumatoid arthritis, originate from plasma (Hamerman, Sandson, and Schubert, 1963; Curtiss, 1964), there is evidence to suggest that the protein component of hyaluronateprotein complex is not a serum protein (Blau, Janis, Hamerman, and Sandson, 1965). It is likely that this small amount of protein is contributed by the synovial cells (Roy and others, 1966). In rheumatoid arthritis the amount of this protein bound to the hyaluronate-protein complex is increased (Hamerman and Sandson, 1963). It thus seems reasonable to postulate that the synovial cells do contribute some increased amount of protein to the synovial fluid. The results of methyl green-pyronin stain for RNA, showing a marked increase in staining reaction of synovial cells for RNA in most of the cases, are in agreement with the ultrastructural findings.

\section{Fine Filamentous Fibres (FFF) in Synovial Cells}

Normal synovial cells may at times contain a small amount of intracytoplasmic fine filaments (Barland 
and others, 1962; Ghadially and Roy, 1966). In rheumatoid arthritis many of the synovial cells showed increased amounts of intracytoplasmic fibrillary material. A similar observation has previously been reported by Hirohata and Kobayashi (1964) and Norton and Ziff (1966). Similar filaments have also been described in peritoneal macrophages and blood monocytes (Petris, Karlsbad, and Pernis, 1962), in Langhans' cells of placenta (Lister, 1963), in chondrocytes (Barnett, Cochrane, and Palfrey, 1963; Collins, Ghadially, and Meachim, 1965; Palfrey and Davies, 1966; Meachim and Roy, 1967), and in thymoma (Ghadially and Illman, 1965). The nature and significance of these filaments is obscure, but it is conceivable that they represent a form of intra-cellular degenerative change.

\section{Changes in Vascular Endothelium}

Hirohata and Kobayashi (1964) described many changes occurring in the blood vessels in rheumatoid synovium. These were hyperplasia of the endothelial cells, occlusion of the lumen, loosening of the endothelial cell junctions, and deposition of intracytoplasmic fibrillary material and lipid. Norton and Ziff (1966) could not confirm many of these findings and neither could we except for the marked increase in the fine filamentous fibres in endothelial cells. The significance of this change is not clear, but here too, as in the synovial cells, some form of degenerative change in the endothelium can be postulated.

\section{Rod-shaped Bodies}

Recently Highton and others (1966) have described rod-shaped bodies in the vascular endothelium of rheumatoid synovia and have suggested that these structures may represent a possible infectious agent of aetiological significance. They claim that the rod-shaped bodies seen by them are different from those observed by Weibel and Palade (1964) in normal vessels. Our studies do not support this idea. The rod-shaped bodies found by us in the vessels of rheumatoid synovia are similar in morphology and size to those described by Weibel and Palade. Furthermore, we have observed such structures in the normal synovium of man and rat, and also in cases of osteo-arthritis and traumatic arthritis in man. We therefore cannot accept the idea that these structures are likely to be the causative organisms of rheumatoid arthritis.

\section{Summary}

Six cases of rheumatoid synovitis were studied and the following lesions were noted:

(1) There was a marked increase in Type B synovial cells with associated hyperplasia of rough endoplasmic reticulum systems.

(2) There was an increase in the number of lysosomes and cytolysomes in synovial cells.

(3) Mitochondria showed many abnormalities, such as dilatation with distortion and displacement of cristae, and the formation of giant mitochondria.

(4) There was an increase in the amount of fine filamentous fibres in synovial cells and vascular endothelium. In some cells most of the normal organelles were destroyed and replaced by these fibres.

(5) Lipid droplets were more frequently encountered in rheumatoid than in normal synovium.

(6) Fibrinoid material was seen on the surface of the synovium and as focal deposits in the matrix. Evidence of phagocytosis of this material by synovial cells was observed.

This work was supported by a grant from the Arthritis and Rheumatism Council. We are indebted to Mr. F. W. Holdsworth and the other staff members of the Orthopaedic Department of the Sheffield Royal Infirmary for help in collecting samples. We are grateful to Mr. T. F. Durrant, Miss Ann Malone, and Miss Flizabeth Parry for their technical assistance.

\section{REFERENCES}

Barland, P., Novikoff, A. B., and Hamerman, D. (1962). J. Cell. Biol., 14, 207 (Electron microscopy of the human synovial membrane).

- - - - (1964). Amer. J. Path., 44, 853 (Fine structure and cytochemistry of the rheumatoid synovial membrane, with special reference to lysosomes).

Barnett, C. H., Cochrane, W., and Palfrey, A. J. (1963). Ann. rheum. Dis., 22, 389 (Age changes in articular cartilage of rabbits).

Biava, C. (1963). Lab. Invest., 12, 1179 (Identification and structural forms of human particulate glycogen).

Blau, S., Janis, R., Hamerman, D., and Sandson, J. (1965). Science, 150, 353 (Cellular origin of hyaluronateprotein in the human synovial membrane).

Collins, D. H., Ghadially, F. N., and Meachim, G. (1965). Ann. rheum. Dis., 24, 123 (Intra-cellular lipids of cartilage).

Curtiss, P. H. (1964). J. Bone Jt Surg., 46-A, 873 (Changes produced in the synovial membrane and synovial fluid by disease).

Ghadially, F. N., and Illman, O. (1965). J. Path. Bact., 90, 465 (Naturally occurring thymomas in the European hamster). 
and Roy, S. (1966). Ann. rheum. Dis., 25, 318 (Ultrastructure of rabbit synovial membrane).

Hamerman, D., and Sandson, J. (1963). J. clin. Invest., 42, 1882 (Unusual properties of hyaluronateprotein isolated from pathological synovial fluids).

,-- , and Schubert,M. (1963). J. chron. Dis., 16, 835 (Biochemical events in joint disease).

Highton, T. C., Caughey, D. E., and Rayns, D. G. (1966). Ann. rheum. Dis., 25, 149 (A new inclusion body in rheumatoid synovia).

Hirohata, K., and Kobayashi, I. (1964). Kobe J. med. Sci., 10, 195 (Fine structures of the synovial tissues in rheumatoid arthritis).

Hruban, Z., Spargo, B., Swift, H., Wissler, R. W., and Kleinfeld, R. G. (1963). Amer. J. Path., 42, 657 (Focal cytoplasmic degradation).

Lister, U. M. (1963). J. Obstet. Gynaec. Brit. Emp., 70, 373 (Ultrastructure of the human mature placenta. 1. The maternal surface).

Meachim, G., and Roy, S. (1967). Ann. rheum. Dis., 26, 50 (Intracytoplasmic filaments in the cells of adult human articular cartilage).

Novikoff, A. B., and Essner, E. (1962). J. Cell. Biol., 15, 140 (Cytolysomes and mitochon drial degeneration).

Norton, W. L., and Ziff, M. (1966). Arthr. and Rheum., 9, 589 (Electron microscopic observations on the rheumatoid synovial membrane).

Palfrey, A. J., and Davies, D. V. (1966). J. Anat. (Lond)., 100, 213 (The fine structure of chondrocytes).

Parry, E. W., and Ghadially, F. N. (1965). Cancer, 18, 1026 (Ultrastructure of carcinogen-induced rat sarcoma).

Petris, S. de, Karlsbad, G., and Pernis, B. (1962). J. Ultrastruct. Res., 7, 39 (Filamentous structures in the cytoplasm of normal mononuclear phagocytes).

Reynolds, E. S. (1963). J. Cell. Biol., 17, 208 (The use of lead citrate at high pH as an electron-opaque stain in electron microscopy).

Ropes, M. W., Bennett, G. A., Cobb, S., Jacox, R., and Jessar, R. A. (1959). Ann. rheum. Dis., 18, 49 (Diagnostic criteria for rheumatoid arthritis, 1958 revision).

Roy, S., and Ghadially, F. N. (1966). Ibid., 25, 402 (Pathology of experimental haemarthrosis).

- (1967). Ibid., 26, 26 (Ultrastructure of normal rat synovial membrane). Ultrastructure and autoradiography with tritiated leucine).

Sandson, J., and Hamerman, D. (1962). J. clin. Invest., 41, 1817 (Isolation of hyaluronateprotein from human synovial fluid).

Weibel, E. R., and Palade, G. E. (1964). J. Cell. Biol., 23, 101 (New cytoplasmic components in arterial endothelia).

Wyllie, J. C., Haust, M. D., and More, R. H. (1966). Lab. Invest., 15, 519 (The fine structure of synovial lining cells in rheumatoid arthritis).

—, More, R. H., and Haust, M. D. (1964). Ibid., 13, 1254 (The fine structure of normal guinea-pig synovium).

\section{L'ultrastructure de la membrane synoviale dans l'arthrite rhumatismale}

\section{RÉSUMÉ}

On étudia six cas de synovite rhumatoïde et on nota des lésions suivantes:

(1) augmentation prononcée des cellules synoviales du type $\mathrm{B}$, associée à l'hyperplasie des systèmes réticulaires endoplasmiques grossiers;

(2) augmentation du nombre des lysosomes et des cytolysomes dans les cellules synoviales;

(3) plusieurs anomalies des mitochondries, telles que dilatation, distorsion et déplacement des cristae et formation de mitochondries géantes;

(4) nombre augmenté des fibres filamenteuses fines dans les cellules synoviales et l'endothélium vasculaire; dans certaines cellules la plupart des organelles mornales étaient détruites et remplacées par ces fibres;

(5) des gouttelettes lipides plus fréquentes dans la synoviale rhumatoïde que dans la normale;

(6) matériel fibrinoïde à la surface de la synoviale et sous forme de dépôts focaux dans la matrice et des signes de phagocytose de ce matériel par des cellules synoviales.
La ultrastructura de la membrana sinovial en la artritis reumatoide Sumario

Se estudiaron seis casos de sinovitis reumatoide y se notaron lesiones siguientes:

(1) aumento pronunciado de células sinoviales del tipo B, asociado con una hiperplasia de los groseros sistemas reticulares endoplasmicos;

(2) aumento del número de lisomas y citolysomas en las células sinoviales;

(3) numerosas anomalías de las mitocondrias, tales como dilatación, deformación y desplazamiento de las crestas y creación de mitocondrias gigantes;

(4) número aumentado de fibras filamentosas finas en las células sinoviales y en el endotelio vascular; en ciertas células la mayoría de las organelas normales se vieron destrozadas y sustituidas por estas fibras;

(5) gotitas lípidas más frecuentes en la sinovia reumatoide que en la normal;

(6) material fibrinoide a la superficie de la sinovia y en forma de depósitos focales en la matriz así como evidencia de fagocitosis de este material por células sinoviales. 